\title{
Direct-Indirect Technique Restoration for Non-Carious Cervical Lesions Treatment: a Case Report
}

\section{Técnica Direta-Indireta para Restauração de Lesões Cervicais não Cariosas: um Relato de Caso}

\author{
Antônio Pedro de Souza Júniora ; Eric Felipe Saraiva Soutoa; Silvério de Almeida Souza Torres ${ }^{\mathrm{b}}$; João Lima Rodrigues ${ }^{\mathrm{b}}$; \\ Danilo Cangussu Mendes ${ }^{\mathrm{b}}$
}

\author{
aFaculdades Unidas do Norte de Minas, Department of Dentistry. MG, Brazil \\ ${ }^{b}$ Universidade Estadual de Montes Claros, Department of Dentistry. MG, Brazil. \\ *E-mail: danilocangussuodonto@yahoo.com.br
}

\begin{abstract}
Non-Carious Cervical Lesions are characterized by slow and progressive loss of hard tissue at the level of enamel-cement junction, without bacterial involvement. This work aimed to address a case report of restorative treatment in Class $\mathrm{V}$ cavities in multiple premolars using the directindirect technique with composite resin. A 42 year-old male patient presented for esthetic restorative treatment with the complaint of severe dentin hypersensitivity and wedged-shaped non-carious cervical lesions affecting the maxillary premolars. The restorative treatment chosen was a direct-indirect technique with composite performed into three sessions as follows: making the class $\mathrm{V}$ composite inlays, cementation, and final polishing. The direct-indirect technique as an alternative to the traditional direct technique has the benefits of a better contour of the restoration, since the finishing and polishing are made extraorally. Besides, the control of the polymerization stress and less discomfort to the patient are other advantages. In the case of direct-indirect class V restoration, the advantages far surpass those of the direct technique.
\end{abstract}

Keywords: Hypersensitivity. Tooth Wear. Composites Resins

\section{Resumo}

As Lesões Cervicais Não Cariosas se caracterizam pela perda lenta e progressiva de tecido duro próximo a junção cemento-esmalte, sem envolvimento bacteriano. Este trabalho tem o objetivo de relatar um caso clínico de tratamento restaurador em cavidades do tipo Classe $V$ em pré-molares pela técnica direta-indireta com resina composta. Paciente do sexo masculino, 42 anos, queixava-se de forte sensibilidade e múltiplas Lesões Cervicais Não Cariosas na forma de cunha nos pré-molares superiores. O tratamento restaurador escolhido foi a técnica direta-indireta com resina composta realizado em três sessões distribuídas em confecção da peça em resina composta, cimentação e polimento final. A técnica direta-indireta surge como alternativa a técnica direta tradicional trazendo como beneficios um melhor contorno da restauração, uma vez que esta é acabada e polida fora da boca, além do controle do estresse de polimerização e menor desconforto ao paciente. A intervenção restauradora direta-indireta se mostra eficaz devido ao fato de conseguir contornar dificuldades encontradas em técnicas restauradoras diretas.

Palavras-chave: Hipersensibilidade. Desgaste dos Dentes. Resinas Compostas

\section{Introduction}

In the last decades, the advances in the prevention of dental caries and the changes in society's habits caused a transformation in the dental care profile of the dentists. Thereby, the demand for non-carious disease treatments has increased. Non-carious cervical lesions (NCCL's) are characterized by the slow and progressive loss of hard tissue close to the enamel junction, without bacterial involvement, interfering with structural integrity ${ }^{1}$.

The NCCL's may have various morphologies depending on diverse etiological factors. Actually, these lesions are associated with pain and aesthetic damage. The etiologic factors responsible for their onset and progression are the tension (as a result of excessive misdirected occlusal loads), the friction (resulting from the use of abrasive dentifrices as well as excessive force during brushing) and the biocorrosion (chemical, biochemical, and electrochemical degradation of tooth substance caused by endogenous and exogenous acids), and these mechanisms generally occur in a combined way ${ }^{2}$.

Due to its multifactorial etiology, treatment of NCCL should be multidisciplinary involving the removal or mitigation of the causal factors and the restoration of the cavity to devolve the mechanical characteristics of the tooth structure. The advancement of restorative materials, such as composite resins (CR), has provided better aesthetic and physical properties, presenting a similar behavior to a sound tooth. Moreover, this material shows excellent sculpibility, which facilitates its handling when compared to other restorative materials. Thus, this is the material of choice for most NCCLs ${ }^{3}$.

In this context, a direct restorative technique with composite resin is an excellent alternative for the treatment of NCCL's. However, it has some disadvantages that can be eliminated with the use of the direct-indirect (or semi-direct) 
technique, since it provides a better finish and polishing of its margin, less tension of polymerization contraction, better visualization, and manipulation, and also facilitating periodontal health. However, this technique requires greater experience and preparation for the dentist with finishing/ polishing and cementation technique ${ }^{1}$.

The purpose of this case report was to describe from planning to the performance of a restorative treatment of multiple NCCL's in premolars using the direct-indirect technique with composite resin, in order to optimize class $\mathrm{V}$ restorative procedure.

\section{Case Report}

A 42-year-old male patient, without systemic involvement, sought the University dental clinic complaining of intense sensitivity in the teeth. On intraoral clinical examination, noncarious cervical lesions were identified in right and left upper premolars (Figure 1A). The evaporative test with an air blast showed that these injuries were the source of the discomfort reported by the patient, also contributing to a disharmonious aspect in dental aesthetics. It was also observed parafunctional habits (both sleep and awake bruxism). The patient reported previous orthodontic treatment and a history of restorative treatment in mandibular premolars. Periodontal health was satisfactory and the radiographic examination found no changes in the periradicular structures (Figure 1B).

Figure 1 - A) The initial aspect of the patient. B) Interproximal radiograph. C) Color check of the composite resin. D) Making the bevel

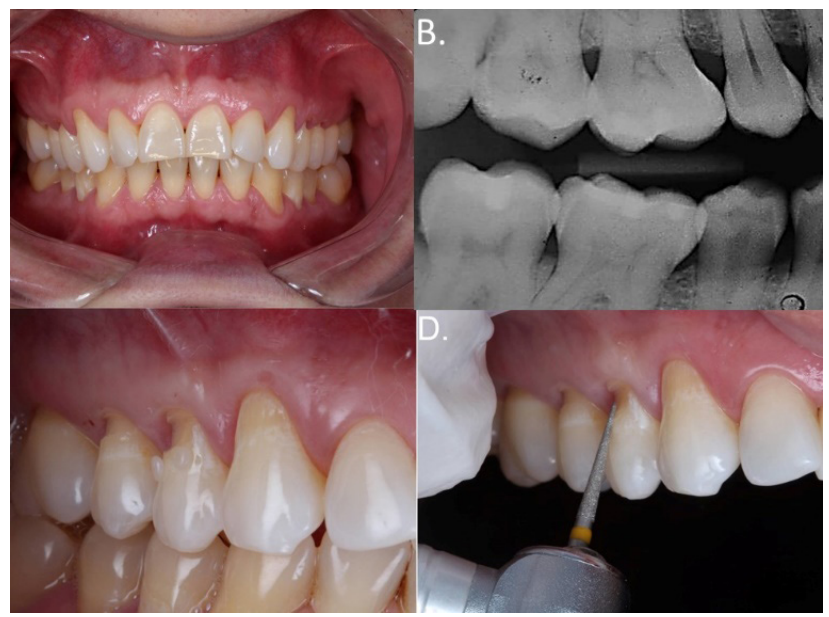

Source: The authors.

The proposed treatment plan involved careful guidance on oral hygiene to the patient followed by basic periodontal treatment. The restorative treatment chosen was the semidirect technique (direct-indirect) with composite resin performed in three sessions distributed in the making of the inlay in composite resin, cementation, and final polishing.

The first restorative step was the prophylaxis with pumice and water. The color of teeth was evaluated under natural light with small increments of composite resin in the cervical region with photoactivation for ten seconds (Figure 1C). The composite resin of choice for the procedure was A3B (Resin Z350, 3M, Saint Paul, Minnesota, EUA) for all teeth to be restored. To start preparing the teeth, anesthesia was first applied to the region of the elements that would receive the restorative intervention, and then the bevel was made at the cavo-superficial angle with a $3195 \mathrm{FF}$ diamond bur (KG Sorensen, Cotia, SP, Brazil) (Figure 1D).

Suprafill insertion spatula for composite resin (Golgran Millennium, São Caetano do Sul/SP, Brazil) was used to insert the non-impregnated retractor cord \# 00 (Ultrapack, Ultradent Products Inc, South Jordan, UT, United States) (Figure 2A) in the gingival sulcus of the teeth that would receive the composite resin, aiming to expose the entire extent of the lesion and, consequently, achieve a better adaptation of the restorative material. The lesion was then lubricated with water-soluble lubricant (Figure 2B) to facilitate the removal of the resin after the first photoactivation.

After the preparation step, the tooth was able to receive the restorative material. An increment of composite resin of considerable size in a ball shape was inserted into the lesion (Figure 2C). The operator's index finger was used with moderate pressure to shape and adapt the material throughout the cavity. In sequence, a pre-anatomy was performed with the spatula, respecting the shape of the dental element followed by photoactivation (Photo Activator Radii-Cal, SDI, Bayswater, Austrália) for ten seconds. The composite inlay was removed with a spatula (Figure 2D) and additional photoactivation was performed on all faces for 60 seconds, aiming to achieve a higher degree of conversion of the composite. These steps were repeated for all teeth with NCCL included in the proposed treatment.

Figure 2 - A) Insertion of the \#00 retractor cord B) Lubrication of the tooth. C) Inserting a composite resin ball to be pressed. D) removal of the photoactivated resin.

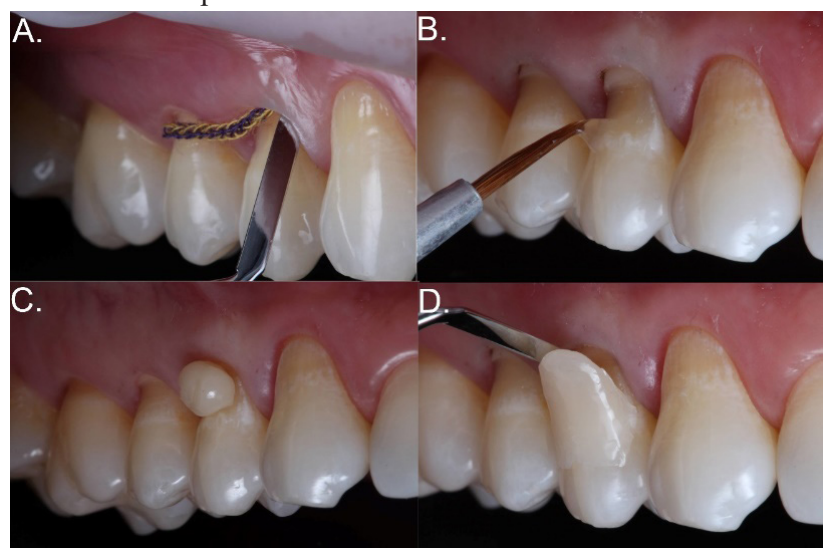

Source: The authors.

A colored grafite was used to mark the limits of preparation in the composite resin (Figure 3A). Then, a Polishing disc (Sof-Lex Pop-On, 3M, Saint Paul, Minnesota, United States) was used to finishing and pre-polishing, removing all coarse excess of restorative material in order to allow an adequate contour (Figure 3B and C). The inlay was taken to the cervical 
lesion to check the adaptation and to prevent any continuity failure when fitting and cementing the resin (Figure 3D).

Figure 3 - A) Demarcation of the end of the restoration B) Marginal finishing with a high abrasive disc. C) Marginal finishing with a low abrasive disc. D) Inlay adaptation test

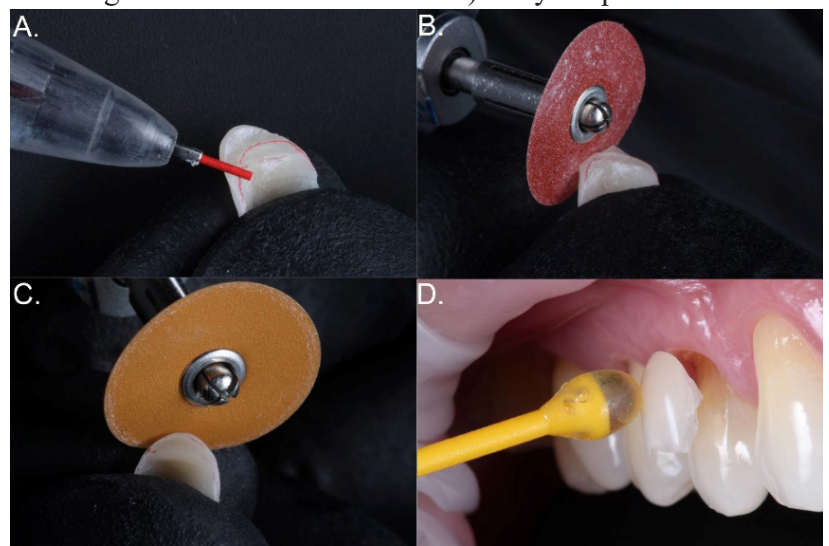

Source: The authors.

The inlay was cleaned with $37 \%$ phosphoric acid (Villevie, Joinville - SC, Brazil) for ten seconds (Figure 4A). After washing the acid, silanization (Angelus) was performed aiming to increase the bond strength of the composite. Subsequently, the adhesive (Adper Single Bond, 3M, Saint Paul, Minnesota, United States) was actively applied (Figure 4B) for 30 seconds followed by photoactivation for 20 seconds.

After inlay's treatment, it was stored in a container protected from the external environment while the substrate treatment was carried out. For dental preparation, conditioning with $37 \%$ phosphoric acid was performed for 30 seconds in enamel and 15 seconds in dentin (Figure 4C) followed by washing the acid and controlling humidity with absorbent paper. Following the manufacturer's protocol, 2 layers of the conventional two-step adhesive system (Figure 4D) were actively applied, volatilizing the solvent between each application and photoactivating only the last layer.

Figure 4 - A) Acid conditioning of the inlay (phosphoric acid $37 \%$ ); B) application of silane and adhesive on the inlay. C) Treatment of the substrate with $37 \%$ phosphoric acid. D) Application of the adhesive system

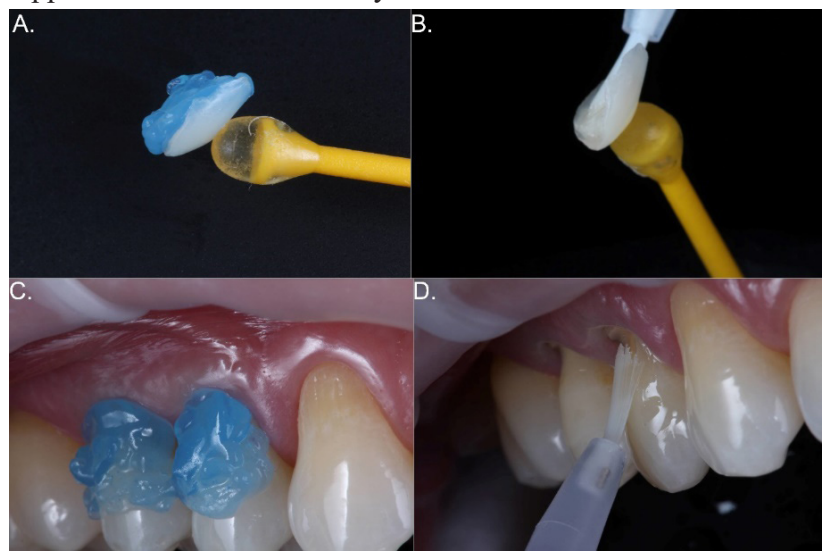

Source: The authors.

For the cementation step, the internal surface of the inlay was filled with dual resin cement (Allcem Core - FGM, Joinville, SC, Brazil) (Figure 5A) and taken to the NCCL applying light pressure for adaptation and extravasation of the cementation material. The overflowing excess was removed with a brush (Figure 5B) and the inlay was stabilized (Figure 5C) and photoactivated for 30 seconds (Figure 5D).

Figure 5 - A) Application of dual resin cement in the inlay B) Removal of excess. C) Inlay's Stabilization. D) Photoactivation

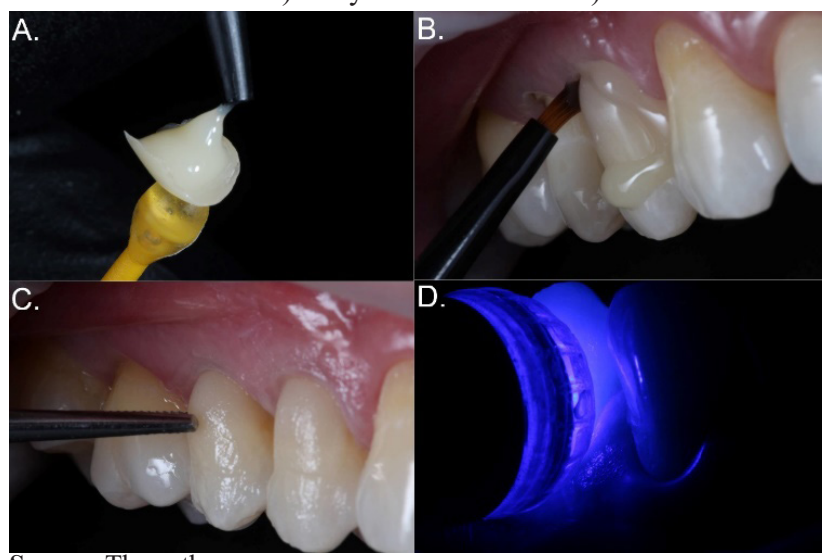

Source: The authors.

Afterward, the cemented restoration was polished. In this step, medium and low abrasive discs (Sof-Lex Pop-On, 3M, Saint Paul, Minnesota, United States) (Figure 6A) were used sequentially to remove coarse grooves. Then an abrasive silicon-impregnated rubber cup (Jiffy, Ultradent Products Inc, South Jordan, UT, United States) (Figure 6B) and medium and low granulation diamond-coated spiral discs (3M, Saint Paul, Minnesota, United States) (Figure 6C and D) were used under irrigation. To finish the polishing, diamond paste (Diamond Excel, FGM, Joinville, SC, Brazil) and felt disc were applied to provide smoothness and shine surface (Figure $6 \mathrm{E}$ and $\mathrm{F}$ ).

Figure 6 - A) Finishing with low granulation disc. B) Abrasive rubber finish. C and D) Pre-polishing with spiral-type discs. E and F) Final polishing with felt and diamond paste

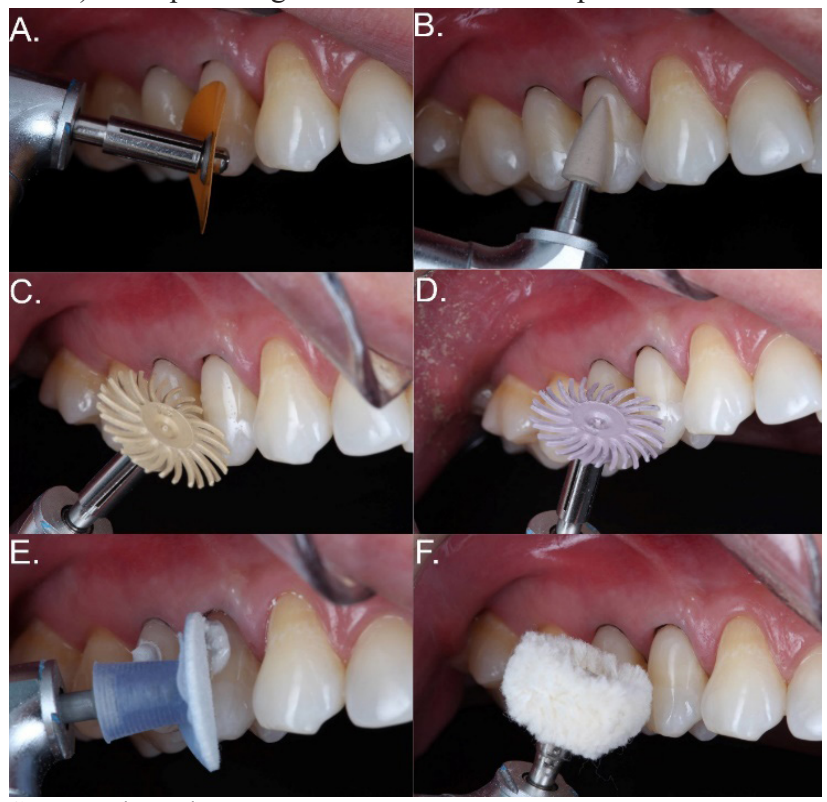

Source: The authors. 
In the last session, after a week of cementation, final polishing was performed, sequentially repeating the polishing steps of the previous session (Figure 7). Clinical follow-up of 1 year was favorable due to the control of plaque and adequate oral hygiene and satisfactory periodontal health (Figure 8A and B).

Figure 7 - Postoperative aspect of the restorations

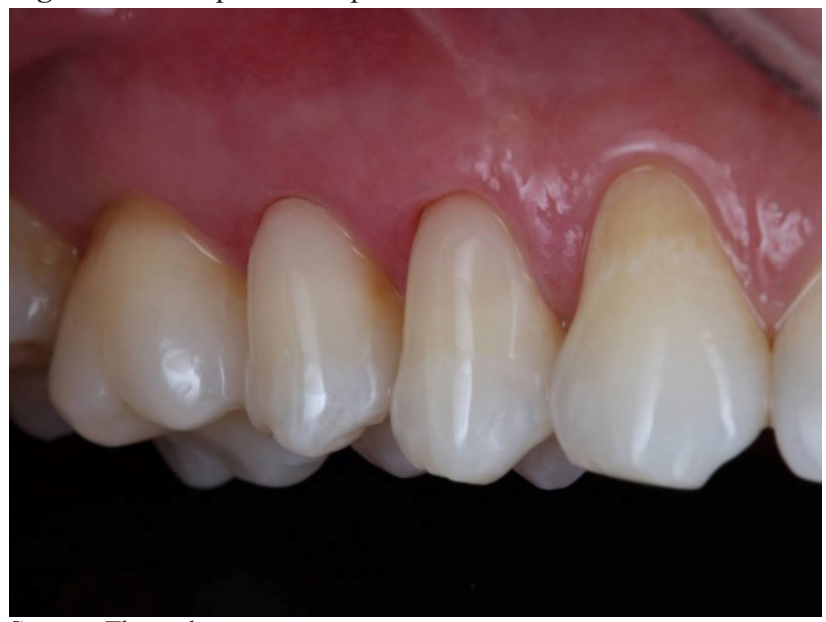

Source: The authors.

Figure 8 - A) Clinical aspect of the restorations after repolishing (12-month follow-up). B) Radiographic control

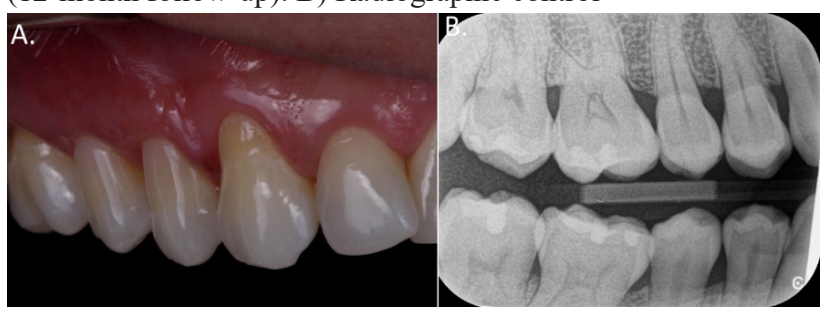

Source: The authors.

This case report was approved by the Research Ethics Committee of the Faculdades Unidas do Norte de Minas (FUNORTE), Montes Claros, Minas Gerais state, Brazil (\#4.226.336). Participant's images and information were obtained through signed informed consent.

\subsection{Discussion}

The prevalence of non-carious diseases has increased worldwide, showing the opposite way to what has been observed about carious injuries ${ }^{4,5}$. This issue is revealed due to the multifactorial nature of the disease, which has a strong influence on the lifestyle of the population, represented by acidic diet, stress, parafunctional habits, and inadequate hygiene habits ${ }^{2}$. Clinical manifestations of NCCL's suggest that the combined mechanisms (Friction, Tension and biocorrosion) are worse than when isolated on the severity and progression of lesions ${ }^{2}$.

In this clinical case report, all restorations were performed due to the development of non-carious cervical lesions in premolar teeth, which is in accordance with the literature that shows that premolars are the most affected teeth by this condition ${ }^{6,7}$. This higher prevalence in premolars can be justified by the cervical constriction that these teeth have, the smaller bone thickness in the buccal surface, and also due to the vertical overlap found in the buccal surface of the premolars, which facilitates a disocclusion in posterior teeth in the movement of laterality in the absence of a canine guide ${ }^{1,8}$.

The use of composite resin for the treatment of NCCL's can be justified through previous studies that show a good retention rate with the use of contemporary adhesive systems, in addition to satisfactory aesthetic properties ${ }^{1,9}$. Untreated NCCL's suffer from the impact of occlusal forces generating stress and fatigue in the cervical region, aggravating the lesions ${ }^{10}$. On the other hand, when restored with composite resin, greater structural resistance is observed due to the mechanical properties of the resin that resemble a sound tooth, which favors the dissipation of force ${ }^{11}$. Novel composites, such as nanoparticulates, micro or nanohybrids, are capable of absorbing part of the energy transmitted during chewing, preserving the tooth-restoration interface ${ }^{12,13}$.

Composite resins can also have an obliterating function concerning exposed dentinal tubules, preventing the transmission of nerve impulses of pain to the pulp that causes dentin hypersensitivity ${ }^{14,15}$. The correct adhesive procedure and restoration in teeth with NCCL's combined to moderate or severe hypersensitivity seems to responded similarly regardless of whether a desensitizing procedure was carried out prior to the filling, showing the efficacy of adhesive procedure to obliterate exposed dentinal tubules, improving quality of life of the patient ${ }^{16}$.

A restorative intervention with composite resin may not be effective due to the challenges encountered in obtaining satisfactory moisture control in the field, as well as the difficulty of accessing the subgingival margins ${ }^{17}$. However, these factors can be minimized, or even solved, using the direct-indirect technique, which appears as an effective alternative for NCCL's restorations. Excellent marginal adaptation, moreefficient polymerization, and greater comfort for the patient are also attributed as advantages of the technique since part of the work is performed outside the mouth ${ }^{18}$.

Given the enumerated benefits, the direct-indirect restorative technique becomes a viable and cost-effective option for class V restorations, especially in multiple NCCL's. However, it may require more operative time and a greater skill of the professional in working extra-oral finishing and polishing techniques. It must be required a learning curve of working with tiny inlays intra and extraorally ${ }^{18}$.

The direct-indirect technique can be considered more comfortable for the patient when comparing to the direct technique. Due to the fact that intraoral working time is reduced, the patient is allowed to rest between restorative steps, minimizing the discomfort of long time of open mouth. Also, the absence of subgingival finishing is another point of comfort for the patient ${ }^{18}$. 


\section{Conclusion}

Dentin hypersensitivity and NCCL are increasingly common conditions, affecting a large part of the young population. The professional must take into account a multifactorial approach to correctly diagnose and treat NCCL and HD in order to improve the patient's quality of life. The direct restorative technique can still be considered the primary indication, however the direct-indirect proves to be useful due to circumventing difficulties found in direct approach, making it a great alternative for aesthetic and functional results. Also, it can be considered the comfort and satisfaction of patient when using direct-indirect approach, once this technique results from the absence of subgingival finishing and lesser intraoral working time.

\section{References}

1. Soares PV, Grippo JO. Noncarious cervical lesions and cervical dentin hypersensitivity etiology, diagnosis, and treatment. São Paulo: Quintessence; 2017.

2. Grippo JO, Simring M, Coleman TA. Abfraction, abrasion, biocorrosion, and the enigma of noncarious cervical lesions: a 20-year perspective. J Esthet Restor Dent 2012;24(1):10-23. doi: 10.1111/j.1708-8240.2011.00487.x.

3. Zuza A, Racic M, Ivkovic N, Krunic J, Stojanovic N, Bozovic $\mathrm{D}$, et al. Prevalence of non-carious cervical lesions among the general population of the Republic of Srpska, Bosnia and Herzegovina 2019;69(4):281-8. doi:10.1111/idj.12462.

4. Peres MA, Macpherson LMD, Weyant RJ, Daly B, Venturelli R, Mathur MR, et al. Oral diseases: a global public health challenge. Lancet 2019;394(10194):249-60. doi: 10.1016/ S0140-6736(19)31146-8.

5. Teixeira DNR, Thomas RZ, Soares PV, Cune MS, Gresnigt MMM, Slot DE. Prevalence of noncarious cervical lesions among adults: A systematic review. J Dent 2020;95:103285. doi: 10.1016/j.jdent.2020.103285.

6. Igarashi Y, Yoshida S, Kanazawa E. The prevalence and morphological types of non-carious cervical lesions (NCCL) in a contemporary sample of people. Odontology 2017;105(4):443-52. doi: 10.1007/s10266-017-0300-y.

7. Teixeira DNR, Zeola LF, Machado AC, Gomes RR, Souza PG, Mendes DC, et al. Relationship between noncarious cervical lesions, cervical dentin hypersensitivity, gingival recession, and associated risk factors: a cross-sectional study.
J Dent. 2018;76:93-7. doi: 10.1016/j.jdent.2018.06.017.

8. Soares PV, Souza LV, Verissimo C, Zeola LF, Pereira AG, Santos-Filho PC, et al. Effect of root morphology on biomechanical behaviour of premolars associated with abfraction lesions and different loading types. J Oral Rehabil 2014;41(2):108-14. doi: 10.1111/joor.12113.

9. Kim SY, Lee KW, Seong SR, Lee MA, Lee IB, Son HH, et al. Two-year clinical effectiveness of adhesives and retention form on resin composite restorations of non-carious cervical lesions. Oper Dent 2009;34(5):507-15. doi: 10.2341/08006C.

10. Grippo JO. Noncarious cervical lesions: the decision to ignore or restore. J Esthet Dent. 1992:55-64. doi: 10.1111/ j.1708-8240.1992.tb00721.x.

11. Pereira FA, Zeola LF, de Almeida Milito G, Reis BR, Pereira RD, Soares PV. Restorative material and loading type influence on the biomechanical behavior of wedge shaped cervical lesions. Clin Oral Investig 2016;20(3):433-41. doi: 10.1007/s00784-015-1523-3.

12. Barbosa L, Prado Jr R, Mendes R. Lesões cervicais nãocariosas: etiologia e opções de tratamento restaurador. Rev Dent 2009;8(18):5-10.

13. Moura AG, Beck H. Materiais restauradores para lesões cervicais não cariosas. Rev Odontol UBC 2017;7(1).

14. Veitz-Keenan A, Barna JA, Strober B, Matthews AG, Collie $\mathrm{D}$, Vena $\mathrm{D}$, et al. Treatments for hypersensitive noncarious cervical lesions: a Practitioners Engaged in Applied Research and Learning (PEARL) Network randomized clinical effectiveness study. J Am Dent Assoc 2013;144(5):495-506. doi: 10.14219/jada.archive.2013.0152.

15. West NX, Lussi A, Seong J, Hellwig E. Dentin hypersensitivity: pain mechanisms and aetiology of exposed cervical dentin. Clin Oral Investig. 2013;17:S9-19. doi: 10.1007/s00784-0120887-x.

16. Freitas SdS, Sousa LLA, Moita Neto JM, Mendes RF, Prado Junior RR. Dentin hypersensitivity treatment of non-carious cervical lesions a single-blind, split-mouth study. J Braz Oral Res 2015;29:1-6. doi: https://doi.org/10.1590/18073107bor-2015.vol29.0045

17. Nascimento MM, Dilbone DA, Pereira PN, Duarte WR, Geraldeli S, Delgado AJ. Abfraction lesions: etiology, diagnosis, and treatment options. Clin Cosmet Investig Dent 2016;8:79-87. doi: 10.2147/CCIDE.S63465.

18. Fahl N, Jr. Direct-Indirect Class V Restorations: A Novel Approach for Treating Noncarious Cervical Lesions. J Esthet Restor Dent. 2015;27(5):267-84. doi: 10.1111/jerd.12151. 